10.53116/pgaflr.2020.1.4

\title{
Protection of a Weaker Party in Public Interest - Material Scope of the Directive on Unfair Trading Practices in Business-to-Business Relationships in the Agricultural and Food Supply Chain
}

\author{
Magdalena Knapp*
}

\footnotetext{
* Magdalena Knapp, PhD, candidate at the Department of Public Economic Law, Faculty of Law, University of Białystok, Poland, e-mail: knapp.magdalena@gmail.com, ORCID: https://orcid. org/0000-0003-0147-3056
}

\begin{abstract}
The article focuses on the scope of the Directive (EU) 2019/633 of the European Parliament and of the Council of 17 April 2019 on unfair trading practices in business-to-business relationships in the agricultural and food supply chain. It discusses recent developments in regulatory approach to unfair trading practices. It analyses steps taken towards uniformity in this area of law within the EU and contemplates whether there is a need for further harmonisation. The article attempts to evaluate the scope of the UTP Directive, focusing mainly on a material scope inherently linked to the notion of "agricultural and food products" and characteristics of unfair trading practices. It also discusses whether Member States should consider widening the national regulations beyond food supply chain so that their scope would cover vertical relationships in every sector of the economy.
\end{abstract}

Keywords: unfair trading practices, B2B, buyer power, bargaining power, agricultural producer, agri-food sector, buyer, supplier

\section{Introduction}

The Directive on unfair trading practices in business-to-business relationships in the agricultural and food supply chain, which entered into force in May 2019 (hereinafter: the UTP Directive) is the final solution to the problem of unfairness and inequality of bargaining power in business-to-business relationships (hereinafter: B2B) reached by EU authorities supported by Member States and other stakeholders. It sums up more than ten years of discussion that began first with actions taken by the European Commission aimed at overcoming challenges faced by the European food supply chain (among them: Wijnands et al., 2019; COM/2008/0321 final, 2008; COM/2009/0591 final, 2009). Throughout the years the issue of unfair trading practices was not limited to the agri-food sector, it was also reviewed in a wider context of the whole supply chain. Having said that, it is noteworthy to consider whether the scope of the regulation should be broadened beyond food supply chain. This issue will be given further consideration in the following sections of the paper. 
The paper gives an assessment of the scope of the UTP Directive with the main focus on material scope inherently linked to the notion of "agricultural and food products."

Although the UTP Directive has many points in common with competition law, they generally do not overlap (on the subject of similarities and divergence between the two regulations see Daskalova, 2019). There are many convergences between both regulations, but their prevailing aim is different. Due to the nature of such practices, competition law is not the best suited tool to eliminate them. In short, the aim and capabilities of competition law prevent it from being an effective tool of counteracting UTP. The comparison of both regulations is particularly compelling given that in most Member States the prohibition of UTP is enforced by NCAs. Nevertheless, these issues go beyond the aim of this paper and its short form.

The remainder of the paper is organised as follows. The next section presents a brief background information on the key factors behind introducing prohibition of UTP and refers to a current state of play in Member States. Section Nature of the probibited practices analyses the characteristics of UTPs in more detail, and section $A$ glance at the scope of the UTP Directive discusses mainly the material scope of the regulation and the personal scope closely related to it. It also discusses whether Member States should consider widening the national regulations to the whole supply chain. Finally, section Conclusion presents the conclusion and suggests some tips for future research on unfair business-to-business practices in the EU.

\section{Overview (regulatory background)}

At the outset it is important to highlight the marked trend towards providing greater legal protection to weaker party, e.g. to the employee or the consumer. Within the EU legal framework, particular attention is paid to consumer protection. However, there is also an increasing number of instruments aimed at protection of the weaker party in B2B relations. One of such instruments is the UTP Directive focusing on protecting a supplier in relation with a larger buyer in the food supply chain.

Until recently, the issue was given little consideration. The concern about significant differences in bargaining power expanded gradually in both economics and law. The main focus of the legislators was on total welfare - and in particular consumer welfare. They have been slow to react to problems that UTPs can present. To some extent UTPs can result in positive effects to consumers, such as reducing the cost of final products (Clarke et al., 2002, p. 187); this makes the harm caused to weaker parties in B2B relations less visible and causes legislators to ignore or overlook the problem.

Therefore the question is: what are the reasons for change in the approach and shift to public enforcement? Most of the UTPs can be successfully tackled by measures of private law. The essence of private law, that is, granting initiative to the party to make use of its rights, turns out to be its weakness in relationships characterised by asymmetric bargaining 
power. Private enforcement was deemed insufficient due to the "fear factor", ${ }^{1}$ hence the need for a state intervention. In this regard, the UTP Directive imposes an obligation on Member States to provide or strengthen a mechanism of public enforcement ${ }^{2}$ which was a novel solution in some countries.

Better bargaining position, even if achieved in accordance with the law and market rules, does not justify imposing unfair conditions on a weaker party in a transaction - unfair in the sense that a weaker party would not have accepted them if there was no stark imbalance in the contractual position of the parties.

In free market economies, trade relies mostly on economic principles and legal equality. Ideally, market equilibrium is achieved automatically with no need of state intervention, though this approach implies no economic differences between market participants. However, with existing inequalities, it only deepens the advantage of the stronger party over the weaker. Consequently, in extreme cases, there is a need to apply non-economic measures, in this case legal measures, in the public interest.

The European Economic and Social Committee also shed some light on the importance of balance between the parties that enables mutual relations based on fairness. The Committee stressed that the protection of a weaker party cannot be a sole rationale for state actions aimed at restoring the disturbed balance. In this regard, the primary objective of regulations on unfair trading practices should be the protection of the economic interest of Member States (COM/2013/37 final, 2013).

However, most of the Member States decided to introduce detailed regulations preventing the abuse of the bargaining position by a stronger party, before any regulatory actions at the EU level. In practice, this led to substantial differences in national legislation. Some countries blacklisted specific trade practices, while others relied on general clauses referring to fairness, good commercial conduct and other principles fundamental to trade system. Depending on the approach adopted by a particular Member State, provisions concerning UTPs are part of competition law (extending its scope beyond EU competition rules) or can be found in different branches of law - including, among others, civil, commercial (laws of general nature) or sector-specific laws (Renda et al., 2014, p. 35-43). This in turn translates into how abusive behavior is defined, what measures are implemented to combat this behavior and what the potential sanctions for non-compliance are. It will also, to some extent, determine the object of protection and the model of enforcement (public, private or the combination of both).

Since it was the Member States that introduced the relevant laws on a national level first, in a way it was a bottom-up harmonisation in this area. As can be expected, this course of action has achieved little in terms of uniformity. The Laws of some Member States were designed to meet particular needs of domestic markets of those countries. This is best illustrated by a simple example of the Member State with one of the highest concentration

\footnotetext{
The "fear factor" is further explained in: Green Paper on unfair trading practices in the business-to-business food and non-food supply chain, COM (2013) 37 final, p. 7-8; Report from the Commission to the European Parliament and the Council on unfair business-to-business trading practices in the food supply chain, COM(2016) 32 final, https://eur-lex. europa.eu/legal-content/EN/TXT/HTML/?uri=CELEX:52016DC0032\&from=PL.

2 Recital 28 of the UTP Directive.
} 
ratio in food retailing. ${ }^{3}$ Lithuania introduced specific legislation on UTP in 2009 - the Law on the Prohibition of Unfair Practices of Retailers. ${ }^{4}$ The Law focuses on protecting suppliers against abusive practices of buyers, which are large retail chains. At the time of its adoption, it applied only to the four largest retail chains: Maxima, Rimi, Iki and Norfa. A characteristic feature of the Lithuanian market was the lack of large international retail chains. The situation changed after 2016, when the German retailer Lidl began to gain an increasing market share, mainly at the expense of Maxima, which is still the largest network with approximately $40 \%$ of the market. ${ }^{5}$ Another significant factor contributing to divergence among the national legislation is the influence of national interest groups and political pressure within Member States.

\section{Nature of the prohibited practices}

Unfair trading practices that are a result of imbalance of bargaining power in vertical B2B relations resemble those covered by consumer law. However, the scope of protection of $\mathrm{B} 2 \mathrm{~B}$ power imbalances is nowhere near to the standard set by consumer law.

Even if the weaker party is not an SME supplier or buyer, it may be facing similar problems of limited freedom of choice, negotiations impediments and dependency in relationship with its stronger counterparty. Superior bargaining power is a relative concept and depends on the circumstances of the particular relationship between parties. The point of reference is bargaining position of the other party, not the reference to the relevant market. The advantage of a stronger party is of economic nature. Economic analyses suggest that the assessment of bargaining power between suppliers and buyers should be made on a case-by-case basis, as it depends greatly on the trade relationship. Even the subject of the transaction can affect distribution of bargaining power between the supplier and the buyer. This means that a similar transaction on another product market can completely alter the balance of bargaining power (Haucap et al., 2013, p. 15-16). The size of an undertaking does not play a key role in the assessment of bargaining power (Heimeshoff \& Klein, 2013, p. 14). It is more important to analyse to what extent a stronger party can limit the freedom of a weaker party (the degree of dependence of the weaker party) or expand its capabilities (Carstensen, 2017, p. 76).

Generally, abuse of a bargaining position consists in imposing contractual conditions on one party (B2B relations) resulting from a stronger position of the other party in a given trade relationship. Abuses will occur in situations where one of the parties uses its bargaining position to achieve economic benefits at the expense of the weaker party. In some cases, a weaker party will accept adverse conditions in order to avoid serious financial losses. Unfair practices may indirectly lead to a foreclosure of competitors from relevant markets. The assessment of the unfairness of behavior is generally determined by its purpose

\footnotetext{
It may also apply to Sweden and Finland, bearing in mind that regulations of both countries have limited scope and are based on consumer protection legislation. See SWD/2018/092 final - 2018/082, 2018.

4 Lietuvos Respublikos mažmeniness prekybos imoniu nesažiningu veiksmu draudimo jstatymas, Valstybès žinios Nr. XI-626, 22.12.2009.

5 Vizbarienè, 2018.
} 
and reference to commonly accepted practices in a specific market. Usually, there is no obligation to prove the suffered damage or impact of the infringement on the market, because the main focus is on the fairness, not the implications of the practice.

A catalogue of unfair practices is open as there is no uniform legal definition of UTP. The following list is based on provisions of national laws, international reports and other "soft law" documents which provide an overview of examples of UTPs, ${ }^{6}$ such as:

- unjustified extension of payment deadlines, exclusion of contractual penalties in the event of late payment;

- introducing unclear or imprecise contractual conditions;

- claims for additional benefits that have no relation to the subject of the contract;

- introducing additional marketing fees, e.g. slotting fees, loyalty fees, charging fees for fictitious services, fixed fees for remaining on the list of suppliers ("pay-to-stay"), participation in the costs of promotion and marketing;

- using excessively detailed product specifications to refuse delivery or reduce the price of goods ordered;

- providing products of lower quality or different parameters than agreed;

- cancelling orders and lowering forecasted last-minute orders (especially in relation to perishable agricultural and food products), setting excessively high minimum order thresholds;

- reducing or delaying deliveries in comparison to previous arrangements;

- unjustified return of unused or unsold products, threatening to withdraw products from the offer;

- claims for payment for the deterioration or loss of agricultural and food products that occurred after the transfer of ownership to the buyer;

- unjustified lowering of prices, unfair price fixing, e.g. encouraging the sale of goods below production costs;

- inadequately high contractual penalties;

- unfair transfer of commercial risk to the other party;

- unilateral changes to the provisions of the contract, including retroactive change of the general terms of delivery and prices;

- unilateral contract termination and exclusivity clauses, e.g. an obligation to make purchases from a selected buyer/supplier;

- territorial limitation of supply.

As it is apparent from the above list, the UTPs can take any form: they are not limited to the provision of the agreement stating the obligations and rights of the parties. UTPs may occur at any stage of the product selling (which is confirmed in Recital 15 of the UTP Directive).

The UTP Directive specifically lists the unfair practices in Article 3(1)-(2). The first list contains practices that are regarded unfair regardless of the circumstances. The second list consists of practices that are deemed fair as long as they are subject of contractual

${ }_{6}$ ICN, 2008, p. 7-9, 20-21, 27-28; COM(2013) 37 final, p. 5-6; Renda et al., 2014, p. 99-100; Article 3 of the UTP Directive; SWD/2018/092 final - 2018/082, 2018, p. 206-225. 
agreement. While it is understandable that certain practices can be justified and bring benefits to the parties, it cannot be ruled out that those practices could also be agreed involuntarily. In result, it gives room for potential abuse by the party exercising significant bargaining power which contrasts quite sharply with the idea behind the UTP Directive.

A short list of prohibited practices obviously has its merits and limitations. On the one hand, an exhaustive list is always flawed in so far as it fails to capture every possible UTP and allows an opportunity to circumvent it. On the other, it provides minimal standard and certainty for economic operators as to what to expect, the biggest advantage possibly being lifting the administrative burden from enforcement authorities, leading to shorter and simplified investigation.

The decision-making practice of the Member States is not extensive, despite the fact that some of the regulations were introduced more than ten years ago. For example, since the relevant law was enacted, only a dozen or so decisions were issued in the Czech Republic (Bejček et al., 2019, p. 17; Úřad pro ochranu hospodářské soutěže, 2018, pp. 32-33; Úřad pro ochranu hospodářské soutěže, 2019, p. 17). The situation is similar in Lithuania (Moisejevas et al., 2019, pp. 191-193; Lietuvos Respublikos Konkurencijos Taryba, 2019, pp. 29-31) and Bulgaria (Dinev, 2019, pp. 51-54). In Slovakia (Blažo et al., 2019, pp. 267) and Hungary (Papp, 2019, pp. 154-156) enforcement authorities are more active, they issued several dozen decisions. ${ }^{7}$ Still, the enforcement authorities were expected to be more active in this field.

In many Member States legislation prohibiting UTP refers to general clauses supplemented by examples of prohibited practices rather than specific lists (SWD/2018/092 final - 2018/082, 2018, pp. 227-236). Member States rely on more or less stringent tests to capture as many prohibited practices as possible, which may imply that it is inefficient to rely solely on an exhaustive list of practices. Moreover, some Member States moved from detailed lists of UTPs to more general categories, e.g. in France ${ }^{8}$ and the Czech Republic (Frischmann \& Šmejkal, 2016, p. 231, 239-240), because the former model was deemed unsuccessful. In order to fulfil requirements of the UTP Directive, those countries are obliged to reestablish the previous model of detailed catalogue of prohibited practices.

\section{A glance at the scope of the UTP Directive}

The personal scope of the UTP Directive indicates that it is focused primarily on the problem of buyer power," giving very limited attention to seller power. The provisions of the UTP Directive apply in situations of imbalance of bargaining power depending on thresholds set in Article 1(2). The introduced categories do not reflect the structure of national agri-food markets, therefore they provide more of a guidance than a ready-made solution. The personal scope of the UTP Directive is improved, though, compared to Proposal for

By comparison, in Poland the enforcement authority issued six decisions since 2017, when the rules on UTP were introduced.

8 As a result of the amendment, in 2019 a list of 13 prohibited practices included in Article L.442-6 of the French Code de commerce was removed and generally formulated categories of prohibited practices were introduced.

9 More on the buyer power with regard to UTP see Gjendemsjø \& Anchustegui, 2019; Carstensen, 2017, p. 38-78. 
a Directive ${ }^{10}$ containing a vague definition referring to the SME category (for a critical analysis of the issue see Piszcz, 2018, pp. 153-154). However, it still has its flaws, such as the lack of "two-sided" protection (Piszcz, 2020, pp. 114-117).

The material scope of the Directive is limited by definition to "agricultural and food products", which covers products listed in Annex I to the TFEU as well as products not listed in that Annex, but processed for use as food using products listed in that Annex [Article 2(1) of the UTP Directive]. Hence, the Directive applies not only to the entire agri-food sector; it goes beyond that. The definition includes mostly food products, but also raw agricultural products, semi-products, food supplements, food for special medical purposes, total diet replacement for weight control, fortified food, novel food, products not intended for human consumption etc. Many of the above mentioned products can be bought in pharmacies and from medical wholesalers. Thus, the Directive applies (to a limited extent) to the entities from the pharmaceutical and the biotech sector (manufacturers, wholesalers, pharmacies). If we also consider residues and waste from the food industries (listed in Annex I) and their intended end-use, say, biofuel industry, then the scope is further extended beyond the narrow and typical understanding of agri-food sector.

A broad definition of agricultural and food product relates to supply chains other than food supply chain. It is somewhat inconsistent with the emphasised need to protect the agri-food sector, and above all, the need to protect agricultural producers (Recital 7 and 10 of the UTP Directive). In the light of above, commentators point even to the questionable legal basis for the Directive (Schebesta et al., 2018).

Another issue is the introduction of a more precise definition of "perishable product" than in the Proposal for a Directive, which should be viewed as an improvement. Currently, perishable agricultural and food products are agricultural and food products that by their nature or at their stage of processing are liable to become unfit for sale within 30 days after harvest, production or processing. It is further clarified that perishable products are products that are normally used or sold quickly (Recital 17 of the UTP Directive); e.g. fruit and vegetable crops are perceived as highly perishable. Perishable products also stand out from other products for their features such as limited shelf time, changes in demand and approach to safety issues of these products. Prohibiting some practices referring to perishable products can prevent or minimalise the risk of food loss and food waste, which is a serious and pervasive problem. It is also economically viable and may enhance the performance of the food chain.

With the above comments in mind, I turn the attention to the issue of the limited scope of the UTP Directive and whether it is sufficiently justified. In the beginning, the discussion on UTP referred to the whole supply chain. ${ }^{11}$ Further along the road it was

\footnotetext{
${ }^{10}$ Proposal for a Directive of the European Parliament and of the Council on unfair trading practices in business-tobusiness relationships in the food supply chain [2018] COM/2018/0173 final (hereinafter, Proposal for a Directive)

${ }^{11}$ COM/2013/036 final, 2013, p. 6-7; COM/2013/37 final. The Resolution of 12.06.2013 of the European Parliament stated that similar regulations could be introduced in other sectors of the economy, to the benefit of consumers; www.europarl.europa.eu/sides/getDoc.do?pubRef=-//EP//TEXT+TA+P7-TA-2013-0268+0+DOC+XML+V0// EN\&language $=E N$. In another resolution of 11.12.2013, the European Parliament clearly stressed that unfair trading practices occur throughout the entire supply chain; www.europarl.europa.eu/sides/getDoc.do?pubRef=-//EP// TEXT+TA+P7-TA-2013-0580+0+DOC+XML+V0/ EN\&language =EN.
} 
slowly constrained to food supply chain. There is no doubt that the agri-food sector has peculiar characteristics. It is also stressed in the UTP Directive (Recital 6). The sector is subjected to many state interventions. States often grant subsidies for specific crops, land subsidies, thus significantly influencing the market dynamics. Such actions affect the structure of the market, the level of concentration and other factors crucial to the functioning of the market. Sometimes this may lead to creation of artificial supply and demand in a given market. Agricultural producers depend on various circumstances, such as: unpredictable weather conditions, geographical conditions, compliance with provisions regarding crop and animal welfare, order-based production which is not uncommon and somewhat reduces the possibility of changing or finding a new buyer.

The food supply chain combines three key sectors for the food industry: agricultural, processing, wholesale and retail distribution. The activities of the agricultural sector include, inter alia, crop production and livestock farming, providing both products for direct consumption as well as raw materials for the processing industry and alternative markets, such as biofuels. The processing industry is at the bottom of the chain. It is diversified because it consists of the production of agricultural goods and animal products as well as basic processing, e.g. refining sugar. The final link in the chain supplying final products to consumers are retailers, such as large retail chains, small local stores, HoReCa etc. (High-Level Group on the Competitiveness of the Agro-Food Industry, 2009). Other features of the food supply chain that lead to its complexity in comparison to other supply chains are the products' perishable feature, price, and demand variation, increasing consumer awareness of food security.

However, despite the distinctive attributes of the food supply chain, UTPs are present in the whole supply chain, and they are detrimental, regardless of the sector in which they occur. It is worth considering to broaden the scope of regulation so that it would capture other sectors, taking into consideration that certain events indicate the need for such actions in some Member States. Recent proceedings initiated by the Polish competition authority can serve as an example. The authority is investigating unfair conduct of wholesalers supplying personal protective equipment to hospitals (UOKIK, 2020). The conduct of wholesalers could include UTP, but due to the limited scope of the Polish Act Counteracting the Unfair Use of Contractual Advantage in the Trade in Agricultural and Food Products, ${ }^{12}$ there is no basis for that. Hence, the authority attempts to tackle it as a competition law infringement. It demonstrates that this issue requires greater public awareness and more attention from policy makers than it has received so far.

As to the Member States, national laws can go beyond definition of food and agricultural product. Therefore, the Member States are not obliged to limit the scope of their existing provisions as long as they are proportionate and compatible with EU law (Recital

\footnotetext{
12 Act of 15 December 2016 on Counteracting the Unfair Use of Contractual Advantage in the Trade in Agricultural and Food Products [Ustawa o przeciwdziałaniu nieuczciwemu wykorzystywaniu przewagi kontraktowej w obrocie produktami rolnymi i spożywczymi] (consolidated text in Journal of Laws of the Republic of Poland 2019, item 517).
} 
39 of the UTP Directive). Some Member States complement laws on UTP by sector specific regulations imposing additional obligations on trade of food and agricultural products. ${ }^{13}$

\section{Conclusion}

The UTP Directive in its form allows for a less uniform regulatory approach to the issue of unfair trading practices. The way some of the provisions were drafted suggests the option to adjust them to specific needs of the country rather than to implement them word by word. On the other hand, the broad discretion given to Member States may pose a potential risk for "gold-plating". Careful scrutiny of national legislation will be required in order to comply with the EU framework.

The standard of minimum harmonisation is laid down in Article 1 of the UTP Directive, allowing for regulatory pluralism. The Member States that had already had national laws in place usually adopted more developed rules on UTP. Hence, the UTP Directive will not bring landmark change for those countries.

Member States should consider broadening the scope of UTP laws beyond the food supply chain as there are no legal obstacles or arguments against extending the regulation to all sectors of the economy. It must be noted that when the European Commission started the consultation process years ago, the debate focused on the occurrence of unfair trading practices in the whole supply chain. Even now, the definition of "agricultural and food product" allows for a broader application of the UTP Directive. Furthermore, the Member States should think of framing useful rules of general application in addition to practices listed in the UTP Directive.

Currently, the map of UTP legislation resembles more a mosaic of various national laws. Regulations of the Member States often contain divergent rules in this respect. It opens up the possibility for opportunistic behavior of international retail chains to apply different practices depending on the country and its regulations. For now, the introduction of the UTP Directive will not significantly change this situation because of its minimum requirements. It is an area of law where EU harmonisation will possibly increase proportionally.

Further action is required to truly approximate the UTP legislation across the EU. A good step towards that goal will be closer cooperation between enforcement authorities and maybe the establishment of a new EU network for UTPs. As in most Member States the designated enforcement authority is NCA, they already have experience in cooperation within the European Competition Network, and now, in the light of the ECN+ Directive,${ }^{14}$ their cooperation will be strengthened.

\footnotetext{
${ }^{13}$ See examples of Central and Eastern European countries in Piszcz \& Jasser (Eds.), 2019.

14 Directive (EU) 2019/1 of the European Parliament and of the Council of 11 December 2018 to empower the competition authorities of the Member States to be more effective enforcers and to ensure the proper functioning of the internal market, OJ L 11, 14.1.2019, p. 3-33.
} 
Since the Member States are still facing the challenge of transposing the provision of the UTP Directive into national laws, there is a dearth of comprehensive evaluation. It remains to be seen whether adopted measures (particularly a list of practices prohibited per $s e$, which is absent in most Member States legislation) are proportionate and appropriate to achieve policy objectives.

\section{References}

Bejček, J., Petr, M., \& Pipková, P. (2019). Czech Republic. In Piszcz, A. \& Jasser, A. (Eds.), Legislation covering business-to-business unfair trading practices in the food supply chain in Central and Eastern European Countries. University of Warsaw, Faculty of Management Press, pp. 85-124.

Blažo, O., Kováčiková, H., \& Patakyová, M. T. (2019). Slovakia. In Piszcz, A. \& Jasser, A. (Eds.), Legislation covering business-to-business unfair trading practices in the food supply chain in Central and Eastern European Countries. University of Warsaw, Faculty of Management Press, pp. 243-270.

Carstensen, P. (2017). Competition Policy and the Control of Buyer Power: A Global Issue. Edward Elgar Publishing. https://doi.org/10.4337/9781782540588

Clarke, R., Davies, R., Dobson, P., \& Waterson, M. (2002). Buyer Power and Competition in European Food Retailing. Edward Elgar Publishing.

Daskalova, V. (2019). The New Directive on Unfair Trading Practices in Food and EU Competition Law: Complementary or Divergent Normative Frameworks? Journal of European Competition Law \& Practice, 10(5), pp. 281-296. https://doi.org/10.1093/jeclap/lpz032

Dinev, A. (2019). Bulgaria. In Piszcz, A. \& Jasser, A. (Eds.), Legislation covering business-to-business unfair trading practices in the food supply chain in Central and Eastern European Countries. University of Warsaw, Faculty of Management Press, pp. 41-62.

Frischmann, P., \& Šmejkal, V. (2016). 2016 Amendment of the Czech Significant Market Power Act of 2009. Yearbook of Antitrust and Regulatory Studies 9(14), pp. 227-246. https://doi.org/10.7172/1689-9024.YARS.2016.9.14.11

Gjendemsjø, R., \& Anchustegui, I. H. (2019). The Scope for National Regulation of Unfair Trading Practices. SSRN Electronic Journal. https://doi.org/10.2139/ssrn.3378461

Haucap, J., Heimeshoff, U., Klein, G. J., Rickert, D. \& Wey, C. (2013). Bargaining Power in Manufacturer-Retailer Relationships, Discussion Paper No. 107, Düsseldorf Institute for Competition Economics. https://citeseerx. ist.psu.edu/viewdoc/download?doi=10.1.1.1038.1754\&rep=rep1\&type=pdf

Heimeshoff, U., \& Klein, G. J. (2013). Bargaining Power and Local Heroes. The Relevance of Cross-Category Complementarities for Bargaining Power and Loss Leading. Discussion Paper No. 87, Düsseldorf Institute for Competition Economics - University of Münster. https://editorialexpress.com/cgi-bin/conference/ download.cgi?db_name=IIOC2017\%paper_id=316

High-Level Group on the Competitiveness of the Agro-Food Industry (2009). Report on the Competitiveness of the European Agro-Food Industry. High-Level Group on the Competitiveness of the Agro-Food Industry. https://bit.ly/2zyVQev

ICN (2008). Report on Abuse of Superior Bargaining Power. ICN. https://bit.ly/3gzSSaa

Lietuvos Respublikos Konkurencijos Taryba, (2019). Veiklos Ataskaita. Lietuvos Respublikos Konkurencijos Taryba. https://bit.ly/3gCgdIn

Moisejevas, R., Mikelènas, V., \& Zaščiurinskaité, R. (2019). Lithuania. In Piszcz, A. \& Jasser, A. (Eds.), Legislation covering business-to-business unfair trading practices in the food supply chain in Central and Eastern European Countries. University of Warsaw, Faculty of Management Press, pp. 171-214.

Papp, M. (2019). Hungary. In Piszcz, A., \& Jasser, A. (Eds.), Legislation covering business-to-business unfair trading practices in the food supply chain in Central and Eastern European Countries. University of Warsaw, Faculty of Management Press, pp.147-170. 
Piszcz, A. (2018). The EU 2018 Draft Directive on UTPs in B2B Food Supply Chains and the Polish 2016 Act on Combating the Unfair Use of Superior Bargaining Power in the Trade in Agricultural and Food Products. Yearbook of Antitrust and Regulatory Studies, 11(17), pp. 143-167. https://doi.org/10.7172/1689-9024.YARS.2018.11.17.8

Piszcz, A. (2020). EU Directive on Unfair Trading Practices in Business-to-Business Relationships in the Agricultural and Food Supply Chain: Dipping a Toe in the Regulatory Waters? Balkan Yearbook of European and International Law, pp. 109-127. https://doi.org/10.1007/16247_2019_7

Renda, A., Cafaggi, F., Pelkmans, J., Iamicelli, P., Correia de Brito, A., Mustilli, F., \& Bebber, L. (2014). Study on the Legal Framework Covering Business-to-business Unfair Trading Practices in the Retail Supply Chain. Final Report. European Commission. https://bit.ly/2Xefp4J

Schebesta, H., Purnhagen, K. P., Keirsbilck, B., \& Verdonk, T. (2018). Unfair Trading Practices in the Food Chain: Regulating Right? Wageningen Working Paper Law and Governance 3, pp 1-20. https://bit. ly/3dhuibR https://doi.org/10.2139/ssrn.3267118

UOKIK (2020, March 4). UOKiK's proceedings on wholesalers' unfair conduct towards hospitals. UOKIK. https://www.uokik.gov.pl/news.php?news_id=16277\&news_page $=2$

Úřad pro ochranu hospodářské soutěže (2018). Annual report 2017. Úřad pro ochranu hospodářské soutěže. https://bit.ly/2XfIsVs

Úřad pro ochranu hospodářské soutěže (2019). Annual report 2018. Úřad pro ochranu hospodářské soutěže. https://bit.ly/2XfIsVs

Vizbariené, R. (2018, May 9). „Maximos“ pelnas smuko 20\%. Verslo Žinios. www.vz.lt/prekyba/2018/05/09/ maximos-pelnas-smuko-20?fbclid=IwAR2Ykwgpzxtrm_b3nD16oboqw_EFJePNXJmgmZHCEqfT v62EMrSmWzwiISM.

Wijnands, J. H. M., van der Meulen, B. M. J., \& Poppe, K. J. (Eds.) (2007). Competitiveness of the European food industry An economic and legal assessment 2007. https://bit.ly/2TTLlcB

\section{Legal sources}

Directive (EU) 2019/633 of the European Parliament and of the Council of 17 April 2019 on unfair trading practices in business-to-business relationships in the agricultural and food supply chain (OJ L 111/59).

COM/2013/37 final, Opinion of the European Economic and Social Committee on the 'Green Paper on unfair trading practices in the business to business food and non-food supply chain in Europe', https://bit.ly/3eAcER9

$\mathrm{COM} / 2008 / 0321$ final, Communication from the Commission to the European Parliament, the Council, the European Economic and Social Committee and the Committee of the Regions Tackling the challenge of rising food prices - Directions for EU action https://bit.ly/2Xh1gDY

COM/2009/0591 final, Communication from the Commission to the European Parliament, the Council, the European Economic and Social Committee and the Committee of the Regions - A better functioning food supply chain in Europe, https://bit.ly/2XIId49

COM/2013/036 final, Communication from the Commission to the European Parliament, the Council, the European Economic and Social Committee and the Committee of the Regions Setting up a European Retail Action Plan, https://bit.ly/2Akh4g8

Proposal for a Directive of the European Parliament and of the Council on unfair trading practices in businessto-business relationships in the food supply chain, COM/2018/0173 final

SWD/2018/092 final - 2018/082, Commission Staff Working Document Impact Assessment Initiative to improve the food supply chain (unfair trading practices) Accompanying the document Proposal for a Directive of the European Parliament and of the Council on unfair trading practices in business-to-business relationships in the food supply chain, https://bit.ly/3ctbZmn 